Chirurgia (2020) 115: 600-608

No. 5, September - October

Copyright@ Celsius

http://dx.doi.org/10.21614/chirurgia.115.5.600

\title{
Laparoscopic Inguinal Hernia Repair: Transabdominal Preperitoneal or Totally Extraperitoneal? Results of a 14-year Prospective Study
}

\author{
Vikesh Patel*, Tanya Gupta, Faisal El-Medani, Sanjay Gupta \\ Department of General Surgery, Lister Hospital, Coreys Mill Lane, Stevenage, Hertfordshire, United Kingdom
}

${ }^{*}$ Corresponding author:

Vikesh Patel, MB BChir

Department of General Surgery,

Lister Hospital,

Coreys Mill Lane,

Stevenage, Hertfordshire, SG1 4AB

E-mail: vikesh.patel@hotmail.co.uk

\section{Rezumat}

Repararea laparoscopică a herniei inghinale: preperitoneal transabdominal sau total extraperitoneal? Rezultatele unui studiu prospectiv de 14 ani

Context: Reparatiile laparoscopice ale herniei inghinale sunt cele mai frecvente operatii transabdominale preperitoneale (TAPP) sau total extraperitoneale (TEP). Indicatiile şi rezultatele comparative pentru ambele abordări sunt adesea contradictorii şi, prin urmare, am căutat să le comparăm pe cele două.

Metode:678 reparații consecutive de hernie inghinală laparoscopică (190 TAPP şi 488 TEP) au fost înregistrate prospectiv pe o bază de date în perioada iunie 2004-decembrie 2018. Vârstă, sex, caracteristicile herniei, timpii operatorii, complicația şi datele privind rata de recurență pe 12 luni au fost comparate.

Rezultate: $49,5 \%$ din reparatiile TAPP au fost hernii recurente, iar 95,5\% din reparatiile TEP au fost hernii bilaterale. Pacienții cu TAPP au fost semnificativ mai în vârstă decât pacienții cu TEP (60,65 față de 55,60, p <0,01). Reparatiile unilaterale TAPP au avut un timp operator semnificativ mai scurt decât reparațiile unilaterale TEP (50,94 față de 65,71 minute, $\mathrm{p}=0,01)$. Nu a existat nicio diferență semnificativă în rata generală de complicatii între reparatiile TAPP şi TEP $(6,84 \%$ fată de $7,38 \%, p=0,87)$, iar acest lucru a fost consecvent în diferite grupuri de hernie. Reparatiile TAPP au reapărut la o rată semnificativ mai mare decât reparațiile TEP $(3,16 \%$ față de $0,61 \%, p=0,02)$ per total, dar ratele de recurență nu au fost semnificativ diferite atunci când au fost defalcate pe grupe de hernie. 
Concluzii: Aplicarea principiului larg al utilizării abordării TAPP pentru herniile recurente şi a abordării TEP pentru herniile bilaterale, rezultatele ambelor operațiuni sunt similare.

Cuvinte cheie: hernie inghinală, laparoscopie, preperitoneal transabdominal, total extraperitoneal, rezultate chirurgicale

\begin{abstract}
Background: Laparoscopic inguinal hernia repairs are most commonly either transabdominal preperitoneal (TAPP) or totally extraperitoneal (TEP) operations. The indications and comparative outcome data for both approaches are often conflicting and thus we sought to compare the two.

Methods: 678 consecutive laparoscopic inguinal hernia repairs (190 TAPP and 488 TEP) were prospectively recorded onto a database from June 2004-December 2018. Age, gender, hernia characteristics, operative times, complication and 12-month recurrence rate data were compared.

Results: $49.5 \%$ of TAPP repairs were recurrent hernias, and $95.5 \%$ of TEP repairs were bilateral hernias. TAPP patients were significantly older than TEP patients $(60.65$ versus $55.60, \mathrm{p}<0.01)$. Unilateral TAPP repairs had a significantly shorter operative time than unilateral TEP repairs (50.94 versus 65.71 minutes, $\mathrm{p}=0.01$ ). There was no significant difference in overall complication rate between TAPP and TEP repairs $(6.84 \%$ versus $7.38 \%, \mathrm{p}=0.87)$, and this was consistent across different hernia groups. TAPP repairs recurred at a significantly higher rate than TEP repairs (3.16\% versus $0.61 \%, \mathrm{p}=0.02)$ overall, but recurrence rates were not significantly different when broken down by hernia group.

Conclusions:Applying the broad principle of utilizing the TAPP approach for recurrent hernias and the TEP approach for bilateral hernias, outcomes from both operations are similar.
\end{abstract}

Key words: inguinal hernia, laparoscopy, transabdominal preperitoneal, totally extraperitoneal, surgical outcomes

\section{Introduction}

Synthetic mesh repairs are accepted as the definitive management of inguinal hernias, and can be conducted using an open or laparoscopic approach (1-2). Most authors agree that laparoscopic repair has a quicker recovery time, lower incidence of wound infection and reduced chronic pain (3), although an open approach under local or regional anesthesia may still be preferred in older and comorbid patients, or in units where surgical expertise favours this (1).

The two most frequently used laparoscopic approaches are transabdominal preperitoneal (TAPP) and totally extraperitoneal (TEP) repairs. In a TAPP repair the peritoneum is incised and entered, and a mesh is placed over the defect in the abdominal wall via the peritoneal cavity. Since the peritoneum is entered, this approach involves a greater risk of intra-abdominal organ injury and adhesion formation (4-5). In a TEP repair, an infraumbilical port site is typically used to insert a trocar into the preperitoneal space over which a balloon is subsequently inflated. This surgeon can then place a mesh over the defect in the abdominal wall whilst remaining extraperitoneal. Creating a preperitoneal space using the TEP approach has been deemed by some authors to require greater operative time and expertise compared to the TAPP approach, and a large caseload has been suggested to achieve acceptable outcomes (6).

Though both operations have been in mainstream practice for over two decades, 
there is little consensus regarding which approach is superior. In a 2005 Cochrane review, whilst some studies showed an increased number of port site hernias and visceral injuries associated with TAPP repairs, others demonstrated that TEP repairs were associated with more conversions to open. Overall, the authors concluded that there was insufficient evidence available to draw deductions about the relative effectiveness of TAPP versus TEP and called for further randomised controlled trials and robust observational studies (4). The largest population-based study carried out to date in 2015 analysed the outcomes of 17,587 patients in a German hernia registry and concluded that similar results could be achieved with both approaches (7).

Two recent meta-analyses have attempted to clarify the specific indications for using one approach over the other, but have reached conflicting conclusions. Wei et al. argue that due to the lack of clear benefit from a theoretically more complex TEP approach, TAPP should be used as the first line approach, particularly for less-experienced surgeons (8). However, Chen et al. found that both repairs have their own subtle advantages and disadvantages, and argue that these should be applied to the decision-making process for individual patients. For example, the shorter operative time found with a TAPP approach could benefit an older comorbid patient unable to tolerate prolonged general anesthetic, whilst the shorter hospital stay and reduced postoperative pain they found with a TEP approach could benefit a younger patient population at greater risk of chronic groin pain (9).

Given the lack of clear consensus in the published data regarding the indications and comparative surgical outcomes of both operations, our 14-year analysis aims to compare the indications and outcomes from the TAPP and TEP approach to laparoscopic inguinal hernia repair at our institution. We analyzed patient demographics and hernia characteristics, as well as intraoperative, postoperative and 12 -month complication and recurrence rates in order to ascertain whether either repair is superior when the operating surgeon is given free choice of approach.

\section{Materials and Method}

Institutional ethical approval was granted for the study, which conformed to the standards outlined in the Declaration of Helsinki. Fully anonymized data from all patients who underwent laparoscopic inguinal hernia repair using either the TAPP or TEP approach from June 2004 to December 2018 were prospectively recorded onto a secure prestructured database. Allocation to TAPP or TEP was non-randomised and based on surgical case attributes such as hernia site and previous surgery, as well as surgeon and patient preference. The same two surgeons at a large 700-bed British hospital performed all of the repairs, with each having more than 10 years surgical experience.

Patient demographics including age, gender, hernia characteristics (primary/recurrent/ unilateral/bilateral) and total operative time in minutes were recorded. Patients were evaluated against 10 categories of complications at three time points; intraoperatively, early postoperatively (within 6 weeks at telemedicine follow up) and late postoperatively (at 12 months follow up in clinic). Complication rates were then compared for TAPP versus TEP overall, and for TAPP versus TEP within each hernia group (primary/recurrent/unilateral/ recurrent). Recurrence rates for both repairs were calculated by assessing whether inguinal hernias had recurred within the first 12 postoperative months and were again calculated overall for TAPP versus TEP, as well as for TAPP versus TEP within each hernia group as defined above.

For the purposes of statistical analysis, bilateral inguinal hernia repairs on a single patient were counted as two hernia repairs. Means were compared for statistical significance using an independent two-sample t-test which assumed equal variance for age, but not for operative times following Levene's testing (significance level 0.05). 
Complication and recurrence rates were compared using Fisher's exact test, which was chosen in anticipation of low absolute frequencies in the contingency table. For each analysis a $2 \times 2$ contingency table was utilized with TAPP or TEP as one nominal variable, and the specific complication or recurrence (defined as yes or no) as the other nominal variable. All $\mathrm{p}$-values were assessed against a significance level of 0.05 and were calculated as two-tail, in recognition of the fact that the observed frequencies in the contingency table could produce results in either direction. All statistical analyses were performed using IBM SPSS ${ }^{\circledR}$ Statistics Build 1.0.0.1327.

\section{Results}

Between June 2004 and December 2018, 420 consecutive patients underwent a total of 678 laparoscopic inguinal hernia repairs at our institution (none excluded). 165 patients underwent 190 TAPP repairs and 255 patients underwent 488 TEP repairs. Mean patient age in the TAPP group was $60.65 \pm 13.53$ versus $55.60 \pm 14.85$ in the TEP group $(\mathrm{p}<0.01)$. The average operative duration was $50.94 \pm 12.87$ minutes for unilateral TAPP repairs versus $65.71 \pm 19.20$ minutes for unilateral TEP repairs $(\mathrm{p}<0.05)$, but there was no significant difference in operative times for bilateral TAPP and TEP repairs $(81.11 \pm 14.43$ versus $78.98 \pm 21.27$ minutes, $\mathrm{p}=0.50) .49 .5 \%$ of TAPP repairs were for recurrent hernias compared to just $1.4 \%$ of TEP repairs, and
95.5\% of TEP repairs were for bilateral hernias compared to just $26.3 \%$ of TAPP repairs. These demographics, along with further hernia characteristics, are summarized in Table 1.

The overall complication rate for TAPP and TEP repair was similar at $6.84 \%$ and $7.38 \%$ respectively $(p=0.87)$ and there were no significant differences in complication rates across all 10 subcategories of complications at three timepoints; intraoperatively, early postoperatively and late postoperatively (Table 2). Similarly when broken down by hernia group, there were no significant differences in complication rates between the TAPP and TEP approach (Tables 3-6). Overall, TAPP repairs recurred at a significantly higher rate than TEP repairs $(6 / 190,3.16 \%$ vs $3 / 488,0.61 \%$, $\mathrm{p}=0.03$ ), but recurrence rates were not statistically significantly different when broken down by hernia group (Tables 3-6). Length of time to recurrence was available for 8 of the 9 recurrences, and averaged 8.4 months (range 112 months).

\section{Discussions}

TAPP and TEP laparoscopic inguinal hernia repairs have become increasingly popular since they were first described over twenty years ago (10-11). However, the relative risks and benefits of both approaches continue to be a source of debate. Our data showed that a TAPP approach was generally preferred for unilateral and recurrent inguinal hernia repairs, whilst a TEP approach was preferred for bilateral and primary inguinal hernias

Table 1. Summary of patient demographics, hernia characteristics and operative times with p-values (two-sample t-test)

\begin{tabular}{lccc}
\hline Characteristic & TAPP $(\mathbf{n = 1 9 0 )}$ & TEP $(\mathbf{n = 4 8 8})$ & p-value \\
\hline Age \pm SD (years) & $60.65 \pm 13.53$ & $55.60 \pm 14.85$ & $<0.01$ \\
\hline Sex: M:F (ratio) & $154: 11(14: 1)$ & $246: 9(27: 1)$ & - \\
\hline Primary repair (\%) & $96(50.53)$ & $481(98.57)$ & - \\
\hline Recurrent repair (\%) & $94(49.47)$ & $7(1.43)$ & - \\
\hline Unilateral repair (\%) & $140(73.68)$ & $22(4.51)$ & - \\
\hline Bilateral repair (\%) & $50(26.32)$ & $466(95.49)$ & - \\
\hline Unilateral repair operative time \pm SD (minutes) & $50.94 \pm 12.87$ & $65.71 \pm 19.20$ & $=0.01$ \\
\hline Bilateral repair operative time \pm SD (minutes) & $81.11 \pm 14.43$ & $78.98 \pm 21.27$ & $=0.50$ \\
\hline
\end{tabular}


(Table 1). This is likely because a TEP approach can be more challenging in recurrent hernia repairs (as well as in patients who have previously undergone other lower abdominal surgery), due to scar tissue formation between the layers of the abdominal wall which makes the creation of a preperitoneal space challenging. Similarly, undertaking a TAPP approach for a bilateral hernia repairs would require the surgeon to traverse the width of the abdomen, affording greater risk of intraabdominal organ injury and adhesion formation; remaining extraperitoneal in these cases theoretically reduces this risk. Patients undergoing TAPP repair were on average 5 years older than those undergoing TEP repairs and this reflects the older age of presentation of recurrent (vs primary)

Table 2. Overall comparison of complication and recurrence rates for TAPP and TEP laparoscopic inguinal hernia repairs, with $\mathrm{p}$-values (Fisher's exact test)

\begin{tabular}{lccc}
\hline Complication (\%) & TAPP $(\mathbf{n = 1 9 0 )}$ & TEP $(\mathbf{n = 4 8 8})$ & p-value \\
\hline Intraoperative & & & \\
\hline Open conversion & $0(0)$ & $2(0.41)$ & 1 \\
\hline TEP to TAPP conversion & $0(0)$ & $2(0.41)$ & 1 \\
\hline Bleeding & $0(0)$ & $3(0.61)$ & 0.56 \\
\hline Necessitated drain insertion & $2(1.05)$ & $8(1.64)$ & 0.73 \\
\hline Visceral injury & $1(0.53)$ & $0(0)$ & 0.28 \\
\hline Early postoperative & $3(1.58)$ & $3(0.61)$ & 0.36 \\
\hline Urinary retention & $2(1.05)$ & $5(1.02)$ & 1 \\
\hline Seroma/haematoma/collection & $1(0.53)$ & $0(0)$ & 0.28 \\
\hline Port-site infection & $0(0)$ & $8(1.64)$ & 0.11 \\
\hline Meralgia parasthetica & & \\
\hline Late postoperative & $4(2.11)$ & $5(1.02)$ & 0.28 \\
\hline Prolonged/chronic groin pain & $13(6.84)$ & $36(7.38)$ & 0.87 \\
\hline Overall complication rate & $6(3.16)$ & $3(0.61)$ & 0.02 \\
\hline Recurrence rate & & &
\end{tabular}

Table 3. Comparison of complication and recurrence rates for primary TAPP and TEP laparoscopic inguinal hernia repairs, with p-values (Fisher's exact test)

\begin{tabular}{lccc}
\hline Complication (\%) & $\begin{array}{c}\text { Primary TAPP } \\
(\mathbf{n}=\mathbf{9 6})\end{array}$ & $\begin{array}{c}\text { Primary TEP } \\
(\mathbf{n = 4 8 1})\end{array}$ & p-value \\
\hline Intraoperative & $0(0)$ & $2(0.42)$ \\
\hline Open conversion & $0(0)$ & $2(0.42)$ \\
\hline TEP to TAPP conversion & $0(0)$ & $2(0.42)$ \\
\hline Bleeding & $1(1.04)$ & $8(1.66)$ \\
\hline Necessitated drain insertion & $1(1.04)$ & $0(0)$ \\
\hline Visceral injury & & $3(0.62)$ \\
\hline Early postoperative & $2(2.08)$ & $5(1.04)$ \\
\hline Urinary retention & $1(1.04)$ & $0(0)$ \\
\hline Seroma/haematoma/collection & $0(0)$ & $8(1.66)$ & \\
\hline Port-site infection & $0(0)$ & $5(1.04)$ & 0.66 \\
\hline Meralgia parasthetica & $0(0)$ & $25(7.28)$ \\
\hline Late postoperative & $5(5.21)$ & $2(0.42)$ \\
\hline Prolonged/chronic groin pain & $2(2.08)$ & 0.13 \\
\hline Overall complication rate & &
\end{tabular}


Table 4. Comparison of complication and recurrence rates for recurrent TAPP and TEP laparoscopic inguinal hernia repairs, with $\mathrm{p}$-values (Fisher's exact test)

\begin{tabular}{lccc}
\hline Complication (\%) & $\begin{array}{c}\text { Recurrent TAPP } \\
(\mathbf{n}=\mathbf{9 4})\end{array}$ & $\begin{array}{c}\text { Recurrent TEP } \\
(\mathbf{n}=\mathbf{7})\end{array}$ & p-value \\
\hline Intraoperative & $0(0)$ & $0(0)$ \\
\hline Open conversion & $0(0)$ & $0(0)$ \\
\hline TEP to TAPP conversion & $0(0)$ & $1(14.29)$ \\
\hline Bleeding & $1(1.06)$ & $0(0)$ \\
\hline Necessitated drain insertion & $0(0)$ & $0(0)$ \\
\hline Visceral injury & & $0(0)$ \\
\hline Early postoperative & $1(1.06)$ & $0(0)$ \\
\hline Urinary retention & $1(1.06)$ & $0(0)$ \\
\hline Seroma/haematoma/collection & $1(1.06)$ & $0(0)$ \\
\hline Port-site infection & $0(0)$ & $0(0)$ & \\
\hline Meralgia parasthetica & & $1(14.29)$ & 0.49 \\
\hline Late postoperative & $4(4.26)$ & $1(14.29)$ \\
\hline Prolonged/chronic groin pain & $8(8.51)$ & 0.31 \\
\hline Overall complication rate & $4(4.26)$ &
\end{tabular}

Table 5. Comparison of complication and recurrence rates for unilateral TAPP and TEP laparoscopic inguinal hernia repairs, with p-values (Fisher's exact test)

\begin{tabular}{|c|c|c|c|}
\hline Complication (\%) & $\begin{array}{l}\text { Unilateral TAPP } \\
\quad(n=140)\end{array}$ & $\begin{array}{l}\text { Unilateral TEP } \\
\quad(n=22)\end{array}$ & p-value \\
\hline \multicolumn{4}{|l|}{ Intraoperative } \\
\hline Open conversion & $0(0)$ & $0(0)$ & \\
\hline TEP to TAPP conversion & $0(0)$ & $0(0)$ & \\
\hline Bleeding & $0(0)$ & $0(0)$ & \\
\hline Necessitated drain insertion & $1(0.71)$ & $1(4.55)$ & \\
\hline Visceral injury & $0(0)$ & $0(0)$ & \\
\hline \multicolumn{4}{|l|}{ Early postoperative } \\
\hline Urinary retention & $2(1.43)$ & $0(0)$ & \\
\hline Seroma/haematoma/collection & $2(1.43)$ & $0(0)$ & \\
\hline Port-site infection & $0(0)$ & $0(0)$ & \\
\hline Meralgia parasthetica & $0(0)$ & $0(0)$ & \\
\hline \multicolumn{4}{|l|}{ Late postoperative } \\
\hline Prolonged/chronic groin pain & $3(2.14)$ & $0(0)$ & \\
\hline Overall complication rate & $8(5.71)$ & $1(4.55)$ & 1 \\
\hline Recurrence rate & $5(3.57)$ & $0(0)$ & 1 \\
\hline
\end{tabular}

hernias, which constituted $49.47 \%$ of TAPP repairs but just $1.43 \%$ of TEP repairs. Indeed, the average age of primary TAPP repairs was $57.46 \pm 13.72$ (compared to $63.54 \pm 12.77$ for recurrent TAPP repairs), and this did not significantly differ from the average age of TEP repairs, $55.60 \pm 14.85$, $\mathrm{p}=0.33$ (Table I).

Unilateral TEP repairs took significantly longer to perform than unilateral TAPP repairs, which is a relatively consistent finding in the literature $(9,12-13)$, and reflects the extra time taken to create the preperitoneal space, which is similar for both unilateral and bilateral TEP repairs. There was no significant difference in operative time when comparing bilateral TAPP and TEP repairs as the creation of a single preperitoneal space allows repair of both hernias in a bilateral TEP operation, thus 
Table 6. Comparison of complication and recurrence rates for bilateral TAPP and TEP laparoscopic inguinal hernia repairs, with $p$-values (Fisher's exact test)

\begin{tabular}{lccc}
\hline Complication (\%) & $\begin{array}{c}\text { Bilateral TAPP } \\
(\mathbf{n = 5 0 )}\end{array}$ & $\begin{array}{c}\text { Bilateral TEP } \\
(\mathbf{n}=\mathbf{4 6 6 )}\end{array}$ & p-value \\
\hline Intraoperative & $0(0)$ & $2(0.43)$ \\
\hline Open conversion & $0(0)$ & $2(0.43)$ \\
\hline TEP to TAPP conversion & $0(0)$ & $3(0.64)$ \\
\hline Bleeding & $1(2)$ & $7(1.50)$ \\
\hline Necessitated drain insertion & $1(2)$ & $0(0)$ \\
\hline Visceral injury & & $3(0.64)$ \\
\hline Early postoperative & $1(2)$ & $5(1.07)$ \\
\hline Urinary retention & $0(0)$ & $0(0)$ \\
\hline Seroma/haematoma/collection & $1(2)$ & $8(1.72)$ & \\
\hline Port-site infection & $0(0)$ & $5(1.07)$ & \\
\hline Meralgia parasthetica & & $35(7.51)$ & 0.57 \\
\hline Late postoperative & $1(2)$ & $3(0.64)$ \\
\hline Prolonged/chronic groin pain & $5(10)$ &
\end{tabular}

saving time despite the initially increased complexity of the procedure. This would also explain why TEP operations were preferred for bilateral hernia repairs, as maximum benefit can be derived from this procedure despite creating only a single preperitoneal space. Given the large caseload and over 10 years previous experience of both surgeons involved in the study, operative times in our data set are unlikely to have been affected by potential differences in the surgeon's expertise or training in either approach.

Overall complication rates were comparable between the two approaches $(6.84 \%$ for TAPP versus $7.38 \%$ for TEP, $\mathrm{p}=0.87$ ), and similar to other population-based studies in the literature in which complication rates range from $0.4 \%$ to $6.3 \%(7,12-13)$. Our data compares favorably to the National Institute for Clinical Excellence (NICE), who state that for experienced surgeons, $4.8 \%$ of primary inguinal hernia repairs and $8.6 \%$ of recurrent repairs are expected to present with emergency complications (14), with this figure unlikely to include non-emergent chronic groin pain or meralgia parasthetica as in our analysis. The similarity seen in overall complication rate between the two approaches in our data was mirrored across all ten subcategories of complications at three time points; intraoperatively, early postoperatively and late postoperatively (Table 2). Comparative complication rates within each hernia group (primary/ recurrent/unilateral/bilateral) also demonstrated that regardless of underlying hernia type and primary pathology, complication rates for TAPP and TEP were not significantly different (Tables 3-6).

A significantly higher recurrence rate at $12^{-}$ month clinic follow up was observed for TAPP repairs as compared to TEP repairs $(3.16 \%$ versus $0.61 \%, p=0.03)$. However, of the 6 TAPP-repaired hernias that recurred 4 were already recurrent hernias and similarly of the 3 TEP-repaired hernias that recurred, 1 was already a recurrent hernia. It is well established that recurrent hernia repairs pose greater challenges due to scar tissue and adhesions from previous surgery (14), and are themselves at increased risk of recurrence. To overcome this bias, and similarly to the complication rate data, recurrence rates for TAPP and TEP were further compared between specific underlying hernia group, and these demonstrated no significant differences (Table 3-6).

Our study therefore demonstrates that within the first postoperative year and regardless of underlying hernia type and pathology, 
complication and recurrence rates from TAPP and TEP inguinal hernia repairs in a large British hospital are similar when surgeons are given free choice of approach based on surgical case attributes. Our outcomes also compare favorably to the wider literature (14). This provides justification for our broad principles of preperitoneal dissection in cases of recurrent hernias and previous lower abdominal surgery, with extraperitoneal dissection being relatively indicated in bilateral cases when choosing the surgical approach. It is plausible that if patients are followed up for a prolonged period over many years, differences in complications rates between the two approaches for chronic pain, port-site hernias and recurrence could become apparent. Indeed, some authors have recommended a follow up period of at least 5 years after hernia repairs in order to fully assess outcomes (15).

\section{Limitations}

The small sample size of this study is an obvious limitation to carrying out this analysis at a single institution. However, by focusing our analysis on one surgical team consisting of two surgeons who usually operated together using the same surgical procedure, we were able to ensure that differences in surgical technique across different hospitals, or even between different surgical teams within a single hospital, did not affect our data. Moreover, our caseload is significantly larger than the number suggested in the literature to overcome the learning curve associated with laparoscopic inguinal hernia repair (16). This threshold is quoted as low as 10 cases in some studies for the more complex TEP approach (17), although a more generally accepted minimum figure is 30 cases $(4,16)$, still significantly less than our sample size.

We acknowledge that non-randomised allocation to TAPP and TEP, and instead allocating patients to each operation based on surgical case attributes as well as surgeon and patient preference, may affect complication rates. Indeed choosing a TAPP approach for recurrent hernias seemingly led to the increased overall rate of recurrence seen with this approach. However, the reality is that patients will not be allocated to these approaches in a random fashion, and surgical case attributes and patient factors are always likely to play a role. The TAPP approach for recurrent hernias is a logical preference given the difficulties associated with creating a preperitoneal space in the TEP approach. That our data failed to show a difference in complication rates despite almost half of TAPP repairs being for recurrent hernias demonstrates that even when surgeons are given free choice of approach under ideal conditions, outcomes are similar.

\section{Conclusions}

Generally our approach was to avoid extraperitoneal repairs in recurrent hernias and patients with previous lower abdominal surgery, as scarring makes preperitoneal dissection challenging. Since creation of extraperitoneal space requires more time and expertise maximum benefit is achieved by preferring this technique for primary bilateral inguinal hernia repairs. Using this broad principle, our data demonstrates that regardless of underlying hernia type and pathology, complication and recurrence rates are similar between TAPP and TEP operations. Indeed, guidance from the International Endohernia Society and the National Institute of Clinical Excellence (NICE) recommends that there is sufficient evidence to support both approaches provided surgeons are appropriately trained $(14,18)$. Our data advances on this and makes a case for favouring the TAPP approach for recurrent hernias, and the TEP approach for bilateral cases, with our complication rates when applying these principles comparing favorably to the literature. Future studies should focus on longer-term outcome data in order to ascertain if differences in complications such as chronic pain, recurrence and port-site hernias become apparent over many years of follow up. 


\section{Conflicts of Interest and Source of Funding}

The authors declare no conflicts of interests.

\section{References}

1. Royal College of Surgeons. Commissioning guide: groin hernia [Internet]. 2016 Nov (cited 2020 Apr 4). Available from: https://www.rcseng.ac.uk/-/media/files/rcs/standards-andresearch/commissioning/groin-hernia-commissioning-guide_ published-2016.pdf

2. Lockhart K, Dunn D, Teo S, Ng JY, Dhillon M, Teo E, et al. Mesh versus non-mesh for inguinal and femoral hernia repair. Cochrane Database Syst Rev. 2018;(9):CD011517.pub2.

3. Cavazzola LT, Rosen MJ. Laparoscopic versus open inguinal hernia repair. Surg Clin N Am. 2013;93(5):1269-79.

4. Wake BL, McCormack K, Fraser C, Vale L, Perez J, Grant AM. Transabdominal pre-peritoneal (TAPP) vs totally extraperitoneal (TEP) laparoscopic techniques for inguinal hernia repair. Cochrane Database Syst Rev. 2005;(1):CD004703.

5. Tulin A, Slavu I, Braga V, Mihaila D, Alecu L. TAAP vs. TEP in Inguinal Hernia Repair - What is the Evidence? A Single Center Experience. Chirurgia (Bucur). 2019;114(1):67-72.

6. Zendejas B, Onkendi EO, Brahmbhatt RD, Lohse CM, Greenlee SM Farley DR. Long-term outcomes of laparoscopic totally extraperitoneal inguinal hernia repairs performed by supervised surgical trainees. Am J Surg. 2011;201(3):379-84.

7. Köckerling F, Bittner R, Jacob DA, Seidelmann L, Keller T, Adolf D, et al. TEP versus TAPP: comparison of the perioperative outcome in 17,587 patients with a primary unilateral inguinal hernia. Surg Endosc. 2015;29(12):3750-60.

8. Wei FX, Zhang YC, Han W, Zhang YL, Shao Y, Ni R. Transabdominal Preperitoneal (TAPP) Versus Totally Extraperitoneal (TEP) for Laparoscopic Hernia Repair: A Meta-Analysis. Surg Laparosc
Endosc Percutan Tech. 2015;25(5):375-83

9. Chen LS, Chen WC, Kang YN, Wu CC, Tsai LW, Liu MZ. Effects of transabdominal preperitoneal and totally extraperitoneal inguinal hernia repair: an update systematic review and meta-analysis of randomized controlled trials. Surg Endosc. 2019;33(2):418-28.

10. Arregui ME, Davis CJ, Yucel O, Nagan RF. Laparoscopic mesh repair of inguinal hernia using a preperitoneal approach: a preliminary report. Surg Laparosc Endosc. 1992;2(1):53-8.

11. McKernan JB, Laws HL. Laparoscopic repair of inguinal hernias using a totally extraperitoneal prosthetic approach. Surg Endosc. 1993;7(1):26-8.

12. Gass M, Banz VM, Rosella L, Adamina M, Candinas D, Güller U. TAPP or TEP? Population-Based Analysis of Prospective Data on 4,552 Patients Undergoing Endoscopic Inguinal Hernia Repair. World J Surg. 2012;36(12):2782-6.

13. Gass M, Scheiwiller A, Sykora M, Metzger J. TAPP or TEP for Recurrent Inguinal Hernia? Population-Based Analysis of Prospective Data on 1309 Patients Undergoing Endoscopic Repair for Recurrent Inguinal Hernia. World J Surg. 2016;40(10): 2348-52.

14. National Institute of Health and Care Excellence. Laparoscopic surgery for inguinal hernia repair [Internet]. 2004 Sep (cited 2020 April 4). Available from: https://www.nice.org.uk/guidance/ta83 /resources/laparoscopic-surgery-for-inguinal-hernia-repair-pdf2294817305029

15. Pikoulis E, Daskalakis P, Psallidas N, Karavokyros I, Stathoulopolos A, Godevenos D, et al. Marlex mesh Prefix plug hernioplasty retrospective analysis of 865 operations. World J Surg. 2005;29(2):231-4.

16. Wright D, O'Dwyer PJ. The Learning Curve for Laparoscopic Hernia Repair. Semin Laparosc Surg. 1998;5(4):227-32.

17. Lal P, Kajla RK, Chander J, Ramteke VK. Laparoscopic total extraperitoneal (TEP) inguinal hernia repair: overcoming the learning curve. Surg Endosc. 2004;18(4):642-5.

18. Bittner R, Montgomery MA, Arregui E, Bansal V, Bingener J, Bisgaard T, et al. Update of guidelines on laparoscopic (TAPP) and endoscopic (TEP) treatment of inguinal hernia (International Endohernia Society). Surg Endosc. 2015;29(2):289-321. 